\title{
CORRESPONDENCE
}

\section{CONSTITUTIONAL FACT AND THEORY: A RESPONSE TO CHIEF JUDGE POSNER}

\author{
Deborah Jones Merritt*
}

In his James Madison Lecture on Constitutional Law, Chief Judge Richard Posner chides both professors and judges for devoting too much attention to constitutional theory and too little time to empiricism. ${ }^{1}$ Although I agree with Judge Posner's endorsement of empiricism, I dispute the roles he assigns empiricism and theory. Social science matters when interpreting the Constitution, but not in the way Posner posits. Facts cannot replace constitutional theories, nor can they mechanically resolve questions posed by theory. Instead, empirical knowledge is most useful in unmasking the theoretical assumptions that undergird constitutional law, in focusing those theories, and in contributing to a multidimensional view of society that informs the substance of constitutional law. In this correspondence, I will examine the flaws in Judge Posner's attempt to substitute empiricism for constitutional theory. I will then explore three more constructive roles that empiricism can play in constitutional law.

Posner centers his critique of theoretical decisionmaking on the Supreme Court's 1996 decision in United States $v$. Virginia. ${ }^{2}$ There, the Court held that Virginia violated the Equal Protection Clause by "reserving exclusively to men the unique educational opportunities" of the Virginia Military Institute. ${ }^{3}$ Posner complains that the Court reached this result by ignoring empirical evidence about the small number of women qualified for or interested in VMI's highly disciplined format. Close examination of Posner's protest, how-

* John Deaver Drinko-Baker \& Hostetler Chair in Law, The Ohio State University. A.B. 1977, Harvard; J.D. 1980, Columbia. — Ed. James Brudney, Mark Killenbeck, Andrew Merritt, Barbara Reskin, and participants at a workshop on constitutional theory and empiricism held at the Georgetown University Law Center provided helpful comments on this essay.

1. See Richard A. Posner, Against Constitutional Theory, 73 N.Y.U. L. Rev. 1 (1998).

2. 518 U.S. 515 (1996). Posner also criticizes Romer v. Evans, 517 U.S. 620 (1996), although more summarily. Posner's errors in discussing Romer are similar to those in his treatment of United States v. Virginia. Because Posner focuses most of his fire on the Virginia decision, I concentrate on that case as well.

3. See Virginia, 518 U.S. at 519. 
ever, reveals that Posner disagrees with the Court's theory of the Equal Protection Clause - not with its understanding of the facts. Facts, in Virginia as in other cases, have no life without theory.

Posner begins his lament by quoting the Court's observation that "'neither [VMI's] goal of producing citizen-soldiers nor [its] implementing methodology is inherently unsuitable to women."'4 With undisguised glee, Posner then demands: "How does the Court know?"5 Here, it seems, is an empirically testable assumption that the Court has failed to verify. How can the Court bar operation of VMI as a male-only institution when it has no proof that women are capable of becoming citizen-soldiers or surviving VMI's rigorous training program? ${ }^{6}$

Posner's empirical question masks an essential theoretical assumption. ${ }^{7}$ Posner's theory of the Constitution holds that all nonjudicial government action is presumptively valid: a plaintiff challenging government action must demonstrate the invalidity of that action and satisfy a high burden of proof. The State of Vir-

4. Posner, supra note 1 , at 13 (quoting Virginia, 518 U.S. at 520).

5. Id.

6. Although I focus on theoretical defects in Posner's argument, even his fact-based challenge is oddly misplaced. The Supreme Court's conclusion that neither VMI's goals nor its pedagogy was "inherently unsuitable to women" paralleled an identical determination in the court of appeals. See Virginia, 518 U.S. at 525 (quoting 976 F.2d 890, 899 (4th Cir. 1992)). Both conclusions, in turn, drew upon six days of trial-court testimony dominated by "an array of expert witnesses on each side." 518 U.S. at 523. This testimony established that "[s]ome women, at least, would want to attend [VMI] if they had the opportunity," that "some women ... a are capable of all of the individual activities required of VMI cadets," and that "some women can meet the physical standards [VMI] now impose[s] on men." 518 U.S. at 540-41 (all but first alteration in original) (internal quotation marks omitted) (quoting findings of fact from the lower courts). Indeed, VMI's own expert on educational institutions acknowledged: "I'm not saying that some women don't do well under [the] adversative model [used by VMT], undoubtedly there are some [women] who do." 518 U.S. at 541 (first and third alteration in original) (internal quotation marks omitted) (quoting district court opinion). The VMI trial, therefore, seems to have included exactly the type of empirical evidence Posner seeks.

Late in his lecture, Posner acknowledges that some women might qualify for VMI's training - although without noting that expert testimony in the trial court established just this fact. Even so, Posner suggests, the small number of qualified women compared to qualified men justified Virginia's decision to select candidates based on sex; it would be inefficient for the state to test women individually. See Posner, supra note 1, at 15 . On this point, as on the others I discuss, Posner simply disagrees with the Supreme Court's theory of the Equal Protection Clause. The Court repeatedly has held that sex, like race, should not serve as a proxy for qualifications that can be tested individually. See, e.g., Weinberger v. Wiesenfeld, 420 U.S. 636 (1975); Frontiero v. Richardson, 411 U.S. 677 (1973).

7. As a prelude to his critique, Posner attempts to draw a distinction between constitutional "theory" and "doctrine." See Posner, supra note 1, at 1-4. This distinction, like the attempt to distinguish theory and empiricism, is problematic. Even accepting Posner's theory/doctrine distinction, however, the assumption masked by his empirical question is a theoretical one. It is an overarching view of how judges should confront constitutional questions, incorporating (as many constitutional theories do) Posner's own perspective on the proper role of the judiciary in a democratic society. 
ginia, Posner reasons, concluded that women were unsuited for careers as citizen-soldiers or study at VMI; any challenger must prove the opposite.

The Justices on the contemporary Supreme Court, however, believe that the Equal Protection Clause mandates a different burden of proof when the state distinguishes citizens on the basis of sex. The state must justify the distinction, and that justification must be "exceedingly persuasive." 8 Posner is entitled to disagree with the Supreme Court's theory of the Equal Protection Clause; some people do. The point, however, is that Posner's disagreement is theoretical, not empirical. Posner wants the Court to stay its hand unless it is very sure that women will benefit from VMI's training. But the Court believes that the Equal Protection Clause forbids explicit gender distinctions unless the state can advance a substantial justification for them. The dispute lies in the realm of theory, not fact.

The theoretical disagreement emerges even more clearly when Posner restates the controversy underlying Virginia. "The issue," Posner concludes, "as it would appear to a disinterested student of public policy unburdened by commitment to any of the constitutional theories, is whether excluding women from VMI is likely to do more harm to women ... than including them would do to the mission of training citizen-soldiers."9 This deceptively simple statement, which Posner finds so self-evident, illuminates the theoretical gulf between the Court and him. Under Posner's formulation of the issue in VMI, a plaintiff challenging intentional, state-mandated sex distinctions must prove that the distinctions do more harm to women than they do good for the state. Posner's Equal Protection Clause is a balance on which even equipoise favors discrimination. As long as the harm to women is no greater than the benefits the state hopes to achieve, discrimination is permissible. Posner's "disinterested student of public policy" seems unburdened, not only by "any of the constitutional theories," but by the Fourteenth Amendment itself.

Posner himself finally admits that he cannot abandon constitutional theory in posing empirical questions. ${ }^{10} \mathrm{He}$ even admits that

8. See Virginia, 518 U.S. at 524, 531; J.E.B. v. Alabama ex rel. T.B., 511 U.S. 127, 136-37 \& n.6 (1994); Mississippi Univ. for Women v. Hogan, 458 U.S. 718, 724 (1982).

9. Posner, supra note 1 , at 16.

10. See id. at 18 ("I never meant to suggest that it is possible to approach constitutional issues free from any predispositions, free, that is, from an approach, or if you will, a theory."). The concession, however, appears late in the lecture and Posner treats it briefly. 
his theory of constitutional law is a spartan one that permits judicial intervention only when the challenged government action is truly "outrageous." 11 Such a theory is fully consistent with imposing a heavy burden of proof on challengers to any government action. Posner's theory just isn't the theory espoused by a majority of the current Supreme Court - at least not in cases involving express sex discrimination.

If Posner concedes that he cannot dispense with theory, then what is the point of his tirade "against constitutional theory"? It is, I think, an attempt to disguise theoretical difference as commitment to empirical fact. This is a dangerous use of empiricism. By suggesting that he has eschewed theory in favor of empirical inquiry, Posner deflects attention from his own theoretical assumptions. $\mathrm{He}$ tempts the reader to accept his outrage theory, which is quite different from the modern Court's interpretation of the Equal Protection Clause, by implying that his conclusions depend upon undisputed facts, not controverted theories. Yet Posner's resolution of the VMI controversy delivers just as much theory as any conference of law professors.

Posner's approach misleads on a second level. Throughout his lecture, he raises a single empirical question about VMI's admissions policy, insisting that resolution of the controversy required more knowledge "about the role of women in the military."12 Even if empirical inquiry could resolve the VMI case, why is this the only question, or even the most important one? Just fifteen percent of VMI's graduates entered the military; the rest succeeded in business, law, politics, and other professions. ${ }^{13}$ The school's endowment reflected the material success of its alumni. VMI enjoyed "the largest per-student endowment of all public undergraduate institutions in the Nation."14 VMI students, moreover, depended upon the school's loyal alumni network to secure influential positions in the civilian sector..$^{15}$ United States $v$. Virginia was not a dispute over women in combat; it was a challenge to a state government that invested heavily in educating men for business and political leadership, that succeeded admirably in this endeavor, and that rigorously limited its special training to men.

11. See id. at 18 ("I happen to belong to what I earlier described as the school of 'outrage' ...."); id. at 4-6 (describing further the "outrage" school of constitutional theory).

12. See id. at 22.

13. See Virginia, 518 U.S. at 520,522 .

14. 518 U.S. at 520.

15. See 518 U.S. at 552-53. 
Anyone who has seriously attempted empirical work knows that framing the question is as important as finding the answer. In science, as in law, the questioner has considerable power to control the reply. By suggesting that resolution of the VMI controversy depended on a single empirical question, and that the question was obvious to any examiner, Judge Posner does a second disservice to genuine empirical inquiry. The Supreme Court posed and answered many empirical questions in United States $v$. Virginia: What benefits did VMI confer on its male graduates? Did the state provide comparable opportunities for women? Were some women capable of surviving VMI's rigorous training? The questions were not all ones that Posner wants to ask. ${ }^{16}$ But empiricism offers no standard for selecting questions; only theory does that.

If Posner's empiricism is misdirected, is there a better way to use empirical science in constitutional law? Ironically, Posner's misuse of empiricism points the way to three more constructive uses of social science in constitutional litigation. ${ }^{17}$

First, the process of empirical exploration unmasks constitutional theory. Facts cannot be gathered without asking questions. Demanding empiricism in constitutional law, therefore, requires judges and scholars to formulate research questions. As my brief review of Posner's lecture demonstrates, empirical questions may reveal an author's theoretical assumptions more tellingly than do pages of declarative text. One cannot ask for data without suggesting that the data are relevant. Once the questions have been posed, one must also decide how much evidence is needed and who will bear the burden of production. Just as Posner's empirical questions about the VMI decision disclose his narrow interpretation of the Equal Protection Clause, empirical queries by other theorists unveil their unarticulated assumptions. Empirical inquiry cannot replace constitutional theory, but it can illuminate the half-hidden theories that guide decisionmakers. In that role, empiricism is a useful adjunct to theory.

Second, social science discoveries can influence the substance of constitutional theory - although not in the simple, direct manner many commentators suppose. Some advocates of empiricism imply that judges confronted with constitutional controversies can find

16. Notably, while Posner does raise the last of these questions, the extensive trial court testimony yielded a different answer than the one he prefers. See supra note 6.

17. Social science may fill roles beyond these three. For example, I do not discuss here the role of social science in legitimating constitutional decisions. The three roles I feature here, however, are the ones I consider most important for constitutional theorists and judges using social science. 
answers to those disputes in the pages of social science journals. Posner himself approaches this position by heavily endorsing empiricism over constitutional theory and by suggesting that "[u]ltimately many of the uncertainties [in constitutional law] may be dispelled" by empirical knowledge. ${ }^{18}$

Any attempt to rely exclusively, or even primarily, upon social science to answer constitutional questions is likely to generate bad science and bad law. The Supreme Court has a rather poor record in this regard - even in answering relatively concrete constitutional questions. During the 1970s, for example, the Court had to decide the constitutionality of six-member criminal and civil juries. ${ }^{19}$ Neither constitutional text nor history resolved the conundrum, so the Court adopted a functional view of the constitutional rights to trial by "jury" and turned to social science to determine whether a six-member jury functioned in the same manner as a twelve-member one.20

The Court's dismal performance has been chronicled elsewhere. It cited "studies" that were simply assertions or news reports, invoked other studies with serious methodological flaws, and even relied on works reaching the opposite conclusion from the one stated by the Court."21 As Michael Saks has written, "[t]he quality of social science scholarship displayed in [the jury-size] decisions would not win a passing grade in a high school psychology class."22

It is tempting to solve this problem simply by imploring the Court to work harder at getting the social science right. Indeed, the Court did improve its performance when evaluating the constitutionality of five-member juries in criminal trials. In that case, the Court even intimated regret at its poor showing in the original jurysize cases. ${ }^{23}$ The courts, however, face substantial barriers in attempting to answer constitutional questions with social science: judges are not trained in the scientific method, they depend upon equally untrained parties to present empirical evidence, and the social science itself too often is flawed and malleable. Human beings

18. See Posner, supra note 1 , at 22.

19. See Williams v. Florida, 399 U.S. 78 (1970) (criminal trials); Colgrove v. Battin, 413 U.S. 149 (1973) (civil trials).

20. See Colgrove, 413 U.S. at 157-59; Williams, 399 U.S. at 99-102. 18-19.

21. See Michael J. Saks, Ignorance of Science Is No Excuse, TrIAL, Nov./Dec. 1974, at 18,

22. Id. at 18.

23. See Ballew v. Georgia, 435 U.S. 223, 237-39 \& n.30 (1978) (noting methodological problems with jury-size studies, as well as the Court's reliance on some of those flawed studies in Colgrove). 
and the societies they form are too complex and changeable to generate precise social science answers to constitutional controversies. ${ }^{24}$

Empirical studies, in other words, can't resolve constitutional issues in the way that an almanac tells us the year in which Halley's Comet will next appear or the population of Wisconsin.25 Social science offers no answer key for constitutional questions. But empirical work does contribute significantly to the broader social knowledge that informs constitutional theory. Social science findings help shape judges' and theorists' views of the world around them, and often challenge deeply held beliefs about that world. As our understanding of society shifts, new social perceptions sometimes produce new constitutional meaning. ${ }^{26}$

This was the true role of social science in Brown v. Board of Education. ${ }^{27}$ The nine Justices who rendered that historic opinion surely did not fashion a neutral empirical question - can separate ever be equal? - and then scan the social science literature for an answer. Instead, they most likely reached a social conclusion, that "[s]eparate educational facilities are inherently unequal," 28 through a complex intellectual journey. The journey may have included personal observation of racial interactions, reflection on their own educational experience and that of their children, consideration of contemporary and historical accounts of segregation, fresh memories of a war in which odious racial classifications figured prominently, philosophical musing about the nature of equality, resolution of prior challenges to the separate-but-equal doctrine in higher education, and examination of a growing body of social science literature documenting the effects of segregation. Social science was but one of several strands weaving a picture of an unequal

24. For a similar argument that social science may inform legal decisionmaking but cannot directly determine the content of legal doctrine, see Edward L. Rubin, Law And and the Methodology of Law, 1997 Wis. L. Rev. 521.

25. Recent controversies over the U.S. census cast doubt even on the certainty of the latter social fact. See Department of Commerce v. United States House of Representatives, 67 U.S.L.W. 4090 (U.S. Jan. 25, 1999); Wisconsin v. City of New York, 517 U.S. 1 (1996). If we cannot count the number of people inhabiting a state without controversy, how can we hope to generate clear answers to the hundreds of social questions informing constitutional law?

26. Carol Weiss and Michael Bucuvalas refer to a similar "enlightenment" function of social science research. See Carol H. Weiss \& Mrchael J. Bucuvalas, Soctal Science Research AND DeCISION-MAKING (1980); Carol H. Weiss, Broadening the Concept of Research Utilization, Soc. SyMP., Winter 1978, at 20; see also Richard Lempert, "Between Cup and Lip": Social Science Influences on Law and Policy, 10 L. \& PoLY. 167, 183-85 (1988) (discussing the "conceptual" or "enlightenment" functions of social science).

27. 347 U.S. 483 (1954).

28. 347 U.S. at 495. 
American society. The composite picture pushed the Justices to embrace a new constitutional theory. ${ }^{29}$

This indirect, ensemble role of social science does not diminish its importance. On the contrary, contributions by social scientists can be crucial to resolving constitutional issues. Social science vigorously challenges the power of individual, anecdotal conviction. Good empirical work forces us to step outside of our own experience and examine the world from a different perspective. Acquiring that viewpoint greatly enriches constitutional theory. Although social science cannot directly answer constitutional queries, it can alter social perceptions. Those perceptions, in turn, help forge constitutional theory.

A third role for social science lies in creating a dialogue between legal theorists and social researchers. Social science is an ongoing exploration, not a singular destination. Answering one question about social behavior generates half a dozen further inquiries. In part this is because society changes, and social science attempts to ascertain both what is and what can be. Social scientists, moreover, understand that most human behavior is contextual; a change in circumstances often varies behavior.

The open-ended nature of social science inquiries can help constitutional thinkers refine their theories. In the jury-size cases, for example, the Supreme Court posited that a jury's primary function is to prevent government oppression. ${ }^{30}$ This function, the Court thought, can be served as long as a jury includes sufficient members to permit group deliberation and to represent a cross section of the community. ${ }^{31}$ The Court then turned to existing social science literature to determine whether six-member juries serve these functions as well as twelve-member ones.

This attempt to consult an existing body of social science research led to the poor results described above. If, however, the Court had been able to engage social scientists in a longer dialogue over jury size, the outcome might have been more promising. Social researchers, for example, could have pressed the Court to define what it meant by "group deliberation." Does the number of words spoken by each group member matter, or is it the power of one or two dissenters to turn the decisional tide? Researchers could also have asked what constitutes an adequate "cross section"

29. See Deborah Jones Merritt, The Future of Bakke: Will Social Science Matter? 59 Oнто ST. L.J. 1055 (1998) (further discussing the role of social science in deciding Brown).

30. See Williams v. Florida, 399 U.S. 78, 100 (1970).

31. See 399 U.S. at 100. 
of the community. Should a minority composing ten percent of the community be represented on every jury, or on three quarters of those juries? Will representation on less than half of the juries suffice ${ }^{32}$ The dialogue might also have prompted the Court to reexamine some aspects of jury performance that it took for granted. ${ }^{33}$ The questions generated by social science, in other words, would have been as important as the answers in pressing the Court to refine its theory of the jury.

Courts, of course, have little capacity to engage in constructive dialogue. Once a controversy reaches a panel of judges, it must be decided. ${ }^{34}$ This third function of social science in constitutional law, therefore, promises a special place for academics. By engaging social scientists in an ongoing dialogue on social issues, constitutional theorists could broaden our understanding of the social context informing the Constitution and also sharpen interpretations of that document. Legal theorists working with social scientists could deepen both social knowledge and constitutional theory in the years before judges must resolve a controversy.

I end, therefore, with a plea that Chief Judge Posner would endorse: Constitutional theorists should pay more attention to social science. Empiricism won't replace theory; it won't even answer most of the controverted questions. But empiricism will expose the preconceptions underlying constitutional theory, it will stimulate new questions about those theories, and it will enrich the cultural understanding that informs all constitutional law. If empiricism succeeds on these three fronts, it will amply reward the constitutional scholars and judges who pursue it.

32. See Saks, supra note 21 , at 19 (noting that in a population with a $10 \%$ minority group, $72 \%$ of twelve-member juries will include at least one of those minority members, while only $47 \%$ of six-member juries will do so).

33. For example, the Court's assumption that "the reliability of the jury as a factfinder hardly seems likely to be a function of its size," Williams, 399 U.S. at 100-01, proved dubious. See Ballew v. Georgia, 435 U.S. 223, 232-35 (1978) (citing empirical studies).

34. Techniques judges use to avoid or limit constitutional decisions can play an important role in continuing dialogue over social issues. Even under these circumstances, however, the court defers decision so that others may continue the dialogue. 